\title{
Evaluation of Hepatocyte Growth Factor in Iraqi Patients with Acute Myeloid Leukemia: Its Correlation with Clinical Parameters and Response to Induction Therapy
}

\author{
Israa M. Al-Bayaa ${ }^{1}$, Haithem Ahmed Al-Rubaie ${ }^{2 *}$, Haider Hasan Al-Shammari ${ }^{2}$ \\ ${ }^{1}$ Department of Pathology, College of Medicine, University of Kerbala, Iraq; ${ }^{2}$ Department of Pathology, College of Medicine, \\ University of Baghdad, Iraq
}

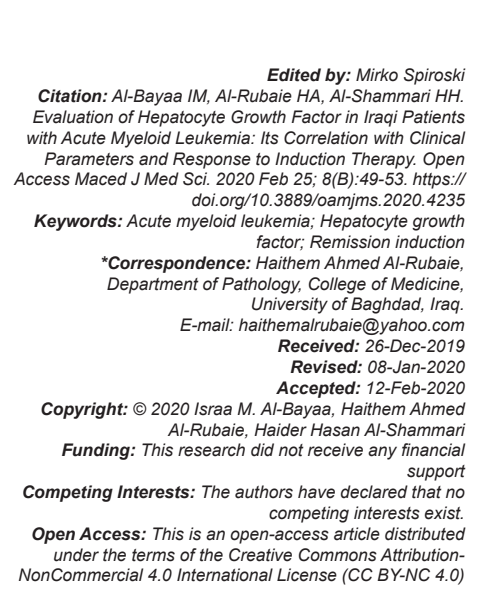

Introduction

Leukemia is an aggressive malignant neoplasm of hemopoietic tissue characterized by progressive uncontrollable proliferation and accumulation of blasts in the bone marrow and peripheral blood [1]. In Iraq, leukemia ranks number three in the top ten types of cancer, accounting for about $6.48 \%$ of total cancers with an incidence rate of 4.3/100,000 [2].

Acute myeloid leukemia (AML) is the most common type of acute leukemia in adults and becomes increasingly common with age. In children, AML accounts for only 10-15\% of childhood leukemia, with slightly more male preponderance [3], [4]. Most cases arise de novo and only $10-20 \%$ of cases are therapyrelated. The etiology of $\mathrm{AML}$ is multifactorial with acquired diseases, environmental factors, and inherited conditions predisposing to its development [5].

Despite advances in understanding the pathogenesis and the impact of molecular defects in the progression of $\mathrm{AML}$, there is variability in remission rates ranging from $50 \%$ to $90 \%$ in adults. This variation reflects the heterogeneity of the disease, the underlying molecular abnormality, and the possibility of other factors that could influence disease progression and treatment response [6], [7].

There is growing evidence that suggests the impact of angiogenesis on leukemia development and treatment response [8]. Many studies have revealed that evaluation of the microvessel density of the bone marrow might have potential prognostic implications in patients with AML [9], [10].

Hepatocyte growth factor (HGF) is a polypeptide proangiogenic factor synthesized by mesenchymal cells, which acts to regulate diverse biological processes that are involved in hemopoietic stem cell survival such as cell growth, apoptosis, and cell adhesion [11]. The cellular responses to HGF are mediated through Met, a cell surface receptor encoded by the c-met proto-oncogene. The effect of HGF in the regulation of angiogenesis maybe by both autocrine and paracrine mechanisms, as both the HGF and its receptor are expressed by vascular tissue [12], [13].

Most studies that address the clinical significance of HGF in AML include all AML subtypes, with different modalities of the treatment regimen. In this study, our aim was to measure HGF levels in adult, 
newly diagnosed, AML patients that received the "7+3" treatment regimen. In our opinion, this would lead to more consistent results and accurate evaluation.

\section{Patients and Methods}

This was a cross-sectional prospective study that included 30 adult newly diagnosed de novo AML patients (14 males and 16 females) who were admitted to the hematology ward of the Medical City Complex. The diagnosis of AML was established by cytomorphology, cytochemistry, and immunophenotyping. Patients' clinical data were all taken at presentation. Patients with secondary AML or acute promyelocytic leukemia were excluded from the study because of the different disease characteristics. Patients who received different treatment options other than $3+7$ treatment protocol ( 3 days of anthracycline "doxorubicin" $30 \mathrm{mg} / \mathrm{m}^{2}$ or daunorubicine $45 \mathrm{mg} / \mathrm{m}^{2}$ and 7 days of cytarabine arabinoside $100 \mathrm{mg} /$ $\mathrm{m}^{2}$ continuous IV) were also excluded from the study. After 21-35 days from the start of chemotherapy, all patients were considered in complete remission $(\mathrm{CR})$ status when: The bone marrow blast cells $<5 \%$, there was absence of Auer rods with recovery of white blood cells (WBC) and platelet counts, and absence of evidence of extramedullary leukemia [14]. Patients were followed up for 6 months to evaluate their clinical outcomes.

The study also included 20 healthy age- and sex-matched medical staff and family members as a control group. They were 11 males and nine females, all of them showed negative reaction to $C$ reactive protein test and normal complete blood counts.

The study was approved by the research ethics committee in College of Medicine, University of Baghdad and was conducted in accordance with the Declaration of Helsinki and informed consent was obtained from all participants.

Blood samples were withdrawn from AML patients twice (at diagnosis and post-induction) and once in control individuals. Venous blood, $2.5 \mathrm{ml}$, was collected from each patient and control in K3-EDTA tubes and used for complete blood counts and blood film smear preparation. Plasma was separated by centrifugation at $1000 \mathrm{~g}$ for $15 \mathrm{~min}$, poured into small aliquots and kept in deep freezer below $-40^{\circ} \mathrm{C}$ until plasma HGF assay was done by sandwich enzyme-linked immunosorbent assay following the manufacturer's instruction [15].

\section{Statistical analysis}

Statistical analyses were done using SPSS version 20 , data are represented as mean \pm standard deviation (SD), median, and interquartile range for continuous data. Non-parametric Mann-Whitney
U-test and Wilcoxon Rank tests were used to compare continuous data. $p<0.05$ was considered significant.

\section{Results}

\section{Clinical parameters}

The mean age for patients' group was 34.67 \pm 12.65 years and the mean age for the control group was $35.15 \pm 11.3$ years. AML was observed in $16(53 \%)$ females and $14(47 \%)$ males with a male:female ratio of 1:1.14. According to subtypes of French-AmericanBritish classification, of the $30 \mathrm{AML}$ cases studied, three were in M1 subtype, 15 were in M2, three were in M4, five were in $\mathrm{M} 5 \mathrm{a}$, and four were in M5b (Figure 1).

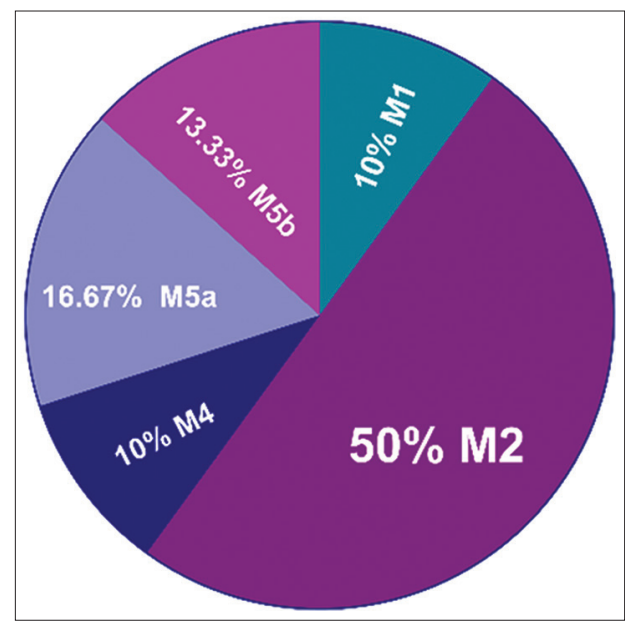

Figure 1: The distribution of patients group among French-AmericanBritish classification

Fever was the most common presentation of patients included in the study $(63 \%)$, followed by pallor $(60 \%)$, extramedullary disease (hepatosplenomegaly and lymphadenopathy) and bleeding in 50\% and 32\%, respectively (Figure 2 ).

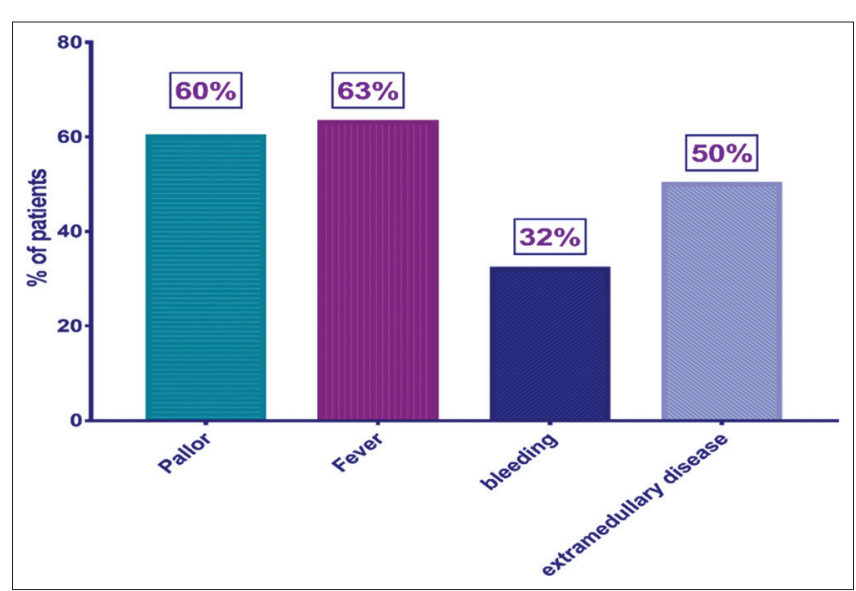

Figure 2: Common signs and symptoms of the patient's group 
Various hematological parameters concerning peripheral blood and bone marrow are demonstrated in Table 1.

Table 1: The median (IQR) of hematological laboratory parameters of the study groups

\begin{tabular}{llll}
\hline Parameters & AML $(\mathrm{n}=30)$ & Control $(\mathrm{n}=20)$ & $\mathrm{p}$ value \\
\hline $\mathrm{Hb} \mathrm{g} / \mathrm{dL}$ & $7.85(2.41)$ & $14.05(1.9)$ & 0.000 \\
WBC $\left(\times 10^{\circ} / \mathrm{L}\right)$ & $22.3(78.73)$ & $6.4(1.83)$ & 0.09 \\
ANC $\left(\times 10^{9} / \mathrm{L}\right)$ & $1.78(4.38)$ & $4.7(1.77)$ & 0.002 \\
Platelet count $\left(\times 10^{9} / \mathrm{L}\right)$ & $45.5(75.8)$ & $284(124)$ & 0.000 \\
PB blasts $\%$ & $47(38.0)$ & - & \\
BM blasts $\%$ & $64(33.5)$ & - & \\
\hline "Mann-Whitney U-test. Hb: Hemoglobin, WBC: White blood cells, ANC: Absolute neutrophil count, \\
PB: Peripheral blood, BM: Bone marrow, IQR: Interquartile range, AML: Acute myeloid leukemia.
\end{tabular}

HGF level in AML patients before and after remission induction therapy and in the control group

The mean $( \pm S D)$ levels of HGF were $3098 \pm$ $3214 \mathrm{pg} / \mathrm{mL}, 1664 \pm 1810 \mathrm{pg} / \mathrm{mL}$, and $702 \pm 188 \mathrm{pg} / \mathrm{mL}$ for $\mathrm{AML}$ patients before remission induction therapy, after therapy, and in the control group, respectively.

There was a statistically significant increase in the median HGF level of patients when compared with control $(p<0.001)$. Furthermore, there was significant reduction in the median HGF level of patients after treatment with $p=0.006$ (Table 2).

\section{Comparison of HGF levels before and} after remission induction therapy in AML Patients' groups according to their response to treatment

AML patients who achieved $\mathrm{CR}$ had a significant reduction in median levels of HGF after

Table 2: Comparison of HGF in AML patients group before and after treatment

\begin{tabular}{llll}
\hline Parameter & AML at presentation & AML After treatment & $p_{\text {value }}$ \\
\hline HGF $(\mathrm{pg} / \mathrm{mL})$ & $1592.5(2409.7)$ & $1094.5(863.3)$ & 0.006 \\
Median (IQR) & $680.7-13838.9$ & $512.2-8664.5$ & \\
\hline Range & Control & $<0.001$ \\
\hline \multicolumn{4}{l}{} \\
\hline
\end{tabular}
factor.

treatment. This was statistically significant $(p=0.003)$, whereas patients with no response had insignificant lowering in median HGF levels after treatment, with $p=0.334$ (Table 3).

\section{Comparison of HGF levels before and after remission induction therapy in AML patients according to extra-medullary involvement (lymphadenopathy and hepatosplenomegaly)}

In AML patients without extramedullary involvement, there was a statistically insignificant decrease in the median level of HGF after treatment, whereas the median level of HGF in patients with
Table 3: Comparison between HGF levels before and after remission induction therapy in AML patients groups according to their response to treatment and to extramedullary involvement

\begin{tabular}{|c|c|c|c|}
\hline \multirow[t]{4}{*}{ Variables } & \multirow{2}{*}{\multicolumn{2}{|c|}{$\begin{array}{l}\text { HGF (pg/mL) } \\
\text { Median (IQR) }\end{array}$}} & \multirow[t]{4}{*}{$p$ value ${ }^{*}$} \\
\hline & & & \\
\hline & \multicolumn{2}{|l|}{ Range } & \\
\hline & Before & After & \\
\hline \multicolumn{4}{|l|}{ Response to treatment } \\
\hline No response $(n=19)$ & $\begin{array}{l}1472.5(985.8) \\
680.7-8470.4\end{array}$ & $\begin{array}{l}1319.2(1026.7) \\
512.2-8664.5\end{array}$ & 0.334 \\
\hline Yes, complete remission $(n=11)$ & $\begin{array}{l}3173.4(4699.3) \\
10128-13838.9\end{array}$ & $\begin{array}{l}885.1(505.7) \\
573.5-1625.7\end{array}$ & 0.003 \\
\hline \multicolumn{4}{|l|}{ Extramedullary involvement } \\
\hline Absent $(n=15)$ & $\begin{array}{l}1600.2(2068.7) \\
680.7-13838.9\end{array}$ & $\begin{array}{l}1140.5(878.6) \\
512.2-8664.5\end{array}$ & 0.191 \\
\hline Present $(n=15)$ & $\begin{array}{l}1584.9(4260.0) \\
956.6-10406.3\end{array}$ & $\begin{array}{l}1048.5(975.6) \\
573.5-3730.2\end{array}$ & 0.005 \\
\hline
\end{tabular}

extramedullary involvement showed a significant statistical reduction after treatment, $p=0.005$ (Table 3).

\section{Comparison of HGF levels in AML patients} according to disease outcome

Six months after remission induction therapy, the total number of $A M L$ patients died was 16. The mean $( \pm S D)$ level of HGF after treatment in patients who remained alive and those deceased was $930 \pm 342$ and $2307 \pm 2300 \mathrm{pg} / \mathrm{mL}$, respectively.

Moreover, the median level of HGF after treatment in deceased patients was remarkably higher than those who remained alive. This observation shows statistically significant difference $(p=0.003)$, whereas the median HGF level before treatment between alive and deceased patients was statistically insignificant with $p=0.377$. A significant decrease in the HGF level was demonstrated in the group of patients who remained alive $(p=0.001)$ unlike the deceased patients in whom the difference was insignificant with a $p=0.501$ (Table 4).

Table 4: Comparison of HGF level in AML patients groups according to disease outcome

\begin{tabular}{|c|c|c|c|}
\hline Parameter & $\begin{array}{l}\text { Alive }(\mathrm{n}=14) \\
\text { Median (IQR) } \\
\text { Range }\end{array}$ & $\begin{array}{l}\text { Deceased }(n=16) \\
\text { Median }(\mathrm{IQR}) \\
\text { Range } \\
\end{array}$ & $p$ value ${ }^{*}$ \\
\hline \multicolumn{4}{|l|}{ HGF (pg/ml) } \\
\hline Before & $\begin{array}{l}2783(5196) \\
681-13839\end{array}$ & $\begin{array}{l}1575(756) \\
798-7740\end{array}$ & 0.377 \\
\hline After & $\begin{array}{l}910.6(533.8) \\
512-1779\end{array}$ & $\begin{array}{l}1480(1218) \\
619-8665\end{array}$ & 0.003 \\
\hline$p$ value $e^{\star *}$ & 0.001 & 0.501 & \\
\hline
\end{tabular}

\section{Discussion}

The impact of angiogenesis over the progression of hematological malignancies has been extensively studied with growing evidence over its implication in the progression of multiple myeloma, acute lymphoid leukemia, and AML [16], [17], [18]. 
HGF is one of the proangiogenic multifunctional cytokines that act through regulating cell adhesion, cell growth, and survival of hemopoietic cells through MET pathway [11].

High levels of HGF in AML patients at diagnosis which declines following induction remission, in particular those who achieved CR support the hypothesis that blasts are potential sources of HGF in patients with AML, besides other sources such as stromal cells and endothelial cells. The eradication of blasts from bone marrow and peripheral blood was associated with a decrease in HGF levels toward normalization and these findings were in agreement with the previous studies [19], [20]. The significant reduction in HGF levels in patients with extramedullary involvement following induction therapy disagree with other studies where a significant differences were demonstrated in both patients with and without extramedullary involvement [19], [21]. No such a difference was found in our study, possibly due to different sample characteristic. For example, in the study of Ahmed et al. [19], patients with all were included in the study, whereas our study only included de novo AML patients, and excluded patients with acute promyelocytic leukemia. The significant reduction in HGF levels we found in patients with extramedullary infiltration could be due to the higher tumor mass in those patients, and the subsequent decrease in levels after therapy may be an indicator of regression in tumor mass.

After 6 months of follow-up, a significant decline in HGF was seen in patients who remained alive. This is consistent with the study of Kim et al. [22], who found that serum HGF was the only parameter that was strongly predictive for $C R$, and that $A M L$ patients with low HGF tend to have better leukemia free survival. Similarly, Verstovsek et al. [23] demonstrated an association between higher levels of HGF and inferior survival in AML patients, and suggested that the enhancement of angiogenesis triggered by this factor and by other proangiogenic factors maybe an explanation for poor response to treatment and inferior outcomes. On the other hand, Hjorth-Hansen et al. [20] used serum samples unlike the other studies that mainly relied on plasma samples, and did not show a significant association between survival and HGF levels. Plasma samples have proven to be more valid and precise when compared to serum samples, as the clotting of blood can induce the release of angiogenic factors from platelets [24].

High HGF levels at presentation may not be significant, as marked reduction of HGF levels after remission induction did not reflect the actual response to treatment. This is because the median level of HGF in alive patients at presentation was much greater than that of the deceased group. Furthermore, there was a significant reduction in HGF levels in the living group and a limited decrease in levels in the deceased group.

The presence of a significant positive correlation between WBC count and serum HGF was also seen in other studies [19], [21], [22] and this may reflect the association between tumour mass and HGF levels.

\section{Conclusion}

Plasma HGF estimation can be a useful parameter in predicting treatment outcomes in patients with $\mathrm{AML}$ and it can add potentially useful information to the risk stratification parameters.

\section{References}

1. Saultz JN, Garzon R. Acute myeloid leukemia: A concise review. J Clin Med. 2016;5(3):e33.

PMid:26959069

2. Obeyed $\mathrm{HH}$, Ibrahim $\mathrm{RH}$, Ali KM, Abdo-Alkareem, Hasan $\mathrm{AH}$, Nasser LM, et al. Annual Report Iraqi Cancer Registry 2016. Baghdad: Iraqi Cancer Board; 2018. Available from: https://moh. gov.iq/upload/upfile/ar/882.pdf

3. Shallis RM, Wang R, Davidoff A, Ma X, Zeidan AM. Epidemiology of acute myeloid leukemia: Recent progress and enduring challenges. Blood Rev. 2019;36:70-87. https://doi.org/10.1016/j. blre.2019.04.005

PMid:31101526

4. Burnett AK, Grimwade D. Acute myeloid leukaemia. In: Hoffbrand AV, Higgs DR, Keeling DM, Mehta AB, editorss. PostgraduateHaematology. $7^{\text {th }}$ ed.Chichester,UK:WileyBlackwell; 2016. p. 352-69. https://doi.org/10.1002/9781118853771.ch20

5. Ossenkoppele G, Montesinos P. Challenges in the diagnosis and treatment of secondary acute myeloid leukemia. Crit Rev Oncol Hematol. 2019;138:6-13.

PMid:31092386

6. De Kouchkovsky I, Abdul-Hay M. Acute myeloid leukemia: A comprehensive review and 2016 update. Blood Cancer J. 2016;6(7):e441. https://doi.org/10.1038/bcj.2016.50 PMid:27367478

7. Döhner $\mathrm{H}$, Weisdorf DJ, Bloomfield CD. Acute myeloid leukemia. N Engl J Med. 2015;373(12):1136-52.

PMid:26376137

8. Haouas H. Angiogenesis and acute myeloid leukemia. Hematology 2014;19(6):311-23.

PMid:24192539

9. Haouas H. Angiogenesis in hematological malignancyevaluated by dynamic contrast-enhanced MRI. J Cancer Res Pract. 2016;3(4):97-103.

10. Reikvam H, Hatfield KJ, Fredly H, Nepstad I, Mosevoll KA Bruserud $\varnothing$. The angioregulatory cytokine network in human acute myeloid leukemia from leukemogenesis via remission induction to stem cell transplantation. Eur Cytokine Netw. 2012;23(4):140-53. https://doi.org/10.1684/ecn.2012.0322 PMid:23328436

11. Roversi FM, Cury NM, Lopes MR, Ferro KP, MachadoNeto JA, Alvarez MC, et al. Up-regulation of SPINT2/HAI-2 by azacytidine in bone marrow mesenchymal stromal cells affects leukemic stem cell survival and adhesion. J Cell Mol Med. 2019;23(2):1562-71. https://doi.org/10.1111/jcmm.14066 
PMid:30484958

12. Guo JR, Li W, Wu Y, Wu LQ, Li X, Guo YF, et al. Hepatocyte growth factor promotes proliferation, invasion, and metastasis of myeloid leukemia cells through PI3K-AKT and MAPK/ERK signaling pathway. Am J Transl Res. 2016;8(9):3630-44. PMid:27725846

13. Jiang W, Hiscox S, Matsumoto K, Nakamura T. Hepatocyte growth factor/scatter factor, its molecular, cellular and clinical implications in cancer. Crit Rev Oncol Hematol. 1999;29(3):20948. https://doi.org/10.1016/s1040-8428(98)00019-5 PMid:10226727

14. Döhner H, Estey E, Grimwade D, Amadori S, Appelbaum FR, Büchner $\mathrm{T}$, et al. Diagnosis and management of AML in adults: 2017 ELN recommendations from an international expert panel. Blood. 2017;129(4):424-47. https://doi.org/10.1182/ blood-2016-08-733196 PMid:27895058

15. Quantikine ${ }^{\circledR}$ ELISA Human HGF Immunoassay Kit (Catalog Number DHG00), R\&D Systems, Inc., 614 McKinley Place NE, Minneapolis, MN 55413, USA. Available from: https://www. rndsystems.com/products/human-hgf-quantikine-elisa-kit dhg00\#product-datasheets. [Last accessed on 2017 Mar 23].

16. Padró T, Ruiz S, Bieker R, Bürger H, Steins M, Kienast J, et al. Increased angiogenesis in the bone marrow of patients with acute myeloid leukemia. Blood. 2000;95(8):2637-44. https://doi. org/10.1182/blood.v95.8.2637 PMid:10753845

17. Vacca A, Ribatti D, Presta M, Minischetti $M$, lurlaro $M$, Ria $\mathrm{R}$, et al. Bone marrow neovascularization, plasma cell angiogenic potential, and matrix metalloproteinase-2 secretion parallel progression of human multiple myeloma. Blood. 1999;93(9):3064-73. https://doi.org/10.1182/blood.v93.9.3064 PMid:10216103

18. Perez-Atayde AR, Sallan SE, Tedrow U, Connors S, Allred E, Folkman J. Spectrum of tumor angiogenesis in the bone marrow of children with acute lymphoblastic leukemia. Am J Pathol.
$1997 ; 150(3): 815-21$.

PMid:9060819

19. Ahmed AE, El-Baser KA, Zytoun SS, Alsenbesy MA, Elsaid AE. Estimation of plasma concentrations of hepatocyte growth factor in acute leukemia in Upper Egypt. Egypt Pediatr Assoc Gaz. 2015;63(1):12-8. https://doi.org/10.4103/1110-1067.155789

20. Hjorth-Hansen $H$, Seidel $C$, Lamvik J, Börset $M$, Sundan A, Waage A. Elevated serum concentrations of hepatocyte growth factor in acute myelocytic leukaemia. Eur J Haematol. 1999;62(2):129-34. https://doi.org/10.1111/j.1600-0609.1999. tb01733.x

PMid: 10052717

21. Aref S, Mabed M, Sakrana M, Goda T, El-Sherbiny M. Soluble hepatocyte growth factor (sHGF) and vascular endothelial growth factor (sVEGF) in adult acute myeloid leukemia: Relationship to disease characteristics. Hematology. 2002;7(5):273-9. https:// doi.org/10.1080/1024533021000037207 PMid: 12850814

22. Kim JG, Sohn SK, Kim DH, Baek JH, Lee NY, Suh JS, et al. Clinical implications of angiogenic factors in patients with acute or chronic leukemia: Hepatocyte growth factor levels have prognostic impact, especially in patients with acute myeloid leukemia. Leuk Lymphoma. 2005;46(6):885-91. https://doi. org/10.1080/10428190500054491

PMid:16019534

23. Verstovsek S, Kantarjian H, Estey E, Aguayo A, Giles FJ, Manshouri $\mathrm{T}$, et al. Plasma hepatocyte growth factor is a prognostic factor in patients with acute myeloid leukemia but not in patients with myelodysplastic syndrome. Leukemia. 2001;15(8):1165-70. https://doi.org/10.1038/sj.leu.2402182 PMid: 11480557

24. Sakon M, Kita Y, Takeda Y, Higaki N, Ohzato H, Umeshita K, et al. Measurement of hepatocyte growth factor in serum and plasma. Int J Clin Lab Res. 1999;29:110-3. https://doi. org/10.1007/s005990050073

PMid:10592107 